\title{
Citizenship Education in Nigeria: For the Young, or the Old?
}

\author{
Anumba, Florence Nnenna \\ Federal College of Education (Technical) Omoku, \\ Rivers State, Nigeria.
}

\section{Doi:10.5901/ ajis.2013.v2n10p37}

\begin{abstract}
Ignorance is a very serious disease which keeps those suffering from it stunted for life. There is a dire need to socialize the entire citizenry, especially children and the youths, who are the leaders of tomorrow, about the society or the State. The organization of instructions, programmes, sensitization, and training for young citizens in a formal school setting cultivates in them desirable habits, values, behavioral patterns, spirit of nationalism and patriotism that instills changes in the citizens towards productive rewards to the state. Every human being is a citizen of a state, but most people are unconscious or ignorant of this. Some, conscious of it, often expect the state to provide them with every human need, while they shy away from contributing to the well-being of the state, owing to their very poor socialization orientation, or a complete lack of it. Citizens are role players in the society; without concrete and effective socialization, they lack the capacity to effectively function productively as members of their state and beyond. This paper advocates an education that can sensitize, socialize and induct the youths on the need to give up their contemporary retaliatory violent and destructive conducts which is threatening the foundation of Nigeria. Such education and punitive measures to purge the adult perpetrators of official corruption and self-enrichment by embezzling public funds, which can further reform feuding leaders from inciting the youths against their opponents in government will usher in the tranquility all of us are yearning for.
\end{abstract}

\section{Introduction}

Nothing can destroy a government more quickly than its failure to observe its own laws, or worse, its disregard of the charter of its own existence (Brandeis 1928). (The National Question, Monday 20 - 23 May, 2013, p.1).

There are multitudes and countless areas or fields of human endeavour, each with its own peculiarity. For one to have a good grip of the embodiment of each or any, one needs education on it. Education may be defined as the training, teaching, sensitization and socialization of a learner towards effective and result oriented performance of roles. Besides, at the mention of citizenship, the individual and the state come to mind. The education of an individual concerning himself and his state that will not only socialize but emancipate and transform him for functional roles in a dynamic society is citizenship education. Ndoh (1997) says that citizenship refers to membership of a given state or nation, and that a citizen can therefore be defined as a legal member of a particular state or country. The 1999 Constitution of the Federal Republic of Nigeria Sections 25(1) and (2), 26(1), 27(1) and (2) and 31 spelt out who can be deemed a Nigeria citizen. We shall unveil this in the later part of this paper.

Citizenship education will enable members of a society acquire full knowledge, not only of the state, but also of their duties and obligations to the state, their rights and expectations from the state, the necessity of total conformity with accepted ways and standards of life of the people, the need for full compliance with rules and regulations and total allegiance to the state. The summary 
of it all is the need for relevant education that will transform the citizens to live legally in the society and contribute meaningfully to its progress. It is this kind of socialization orientation and training that can properly be referred to as education for citizenship. According to Nkang (2007), education should be relevant to the needs of the learner which changes from to time. She added that a lot of things have been done to make the new system relevant to the needs of the Nigerian people.

Every nation has roles towards its nation-building and therefore need capable role players for a strong and reliable nation. To perform their full potentials, the citizens need relevant citizenship education. No one gives what he does not have. Effective and relevant education for citizenship is, therefore, compulsory for all and sundry in a society, particularly the youth in the contemporary period when things are not only falling apart, but are no longer at ease with all races the world over, especially in Nigeria. An I gbo adage says that when a strong bull escapes a strong man goes after it. In recent years, insecurity and crimes in Nigeria have taken the form of piecemeal revolutions. Measures at fighting them should include concrete and effective citizenship education spread out to reach the entire citizenry, especially the young.

\section{Purpose of Citizenship Education}

The purposes of citizenship education are many and varied. They include socializing children against juvenile delinquency, disrespect for elders and all sharp practices that often metamorphose into full-blown crimes. Our youths have acquired international notoriety in such crimes as drug trafficking and addiction, child trafficking, swindling and advance free fraud. For the home-based, the contemporary social ills that plague the nation include: armed robbery, indolence, truancy, smuggling, dishonesty, sharp-practices, and most recently and dangerously kidnapping and suicide bombing. Those in higher institutions pride themselves in cultism, robbery, violence, gross indiscipline, examination mal-practice and campus unrests. There has been public out cry over unemployment against the government, but it has been observed that those who have gained one employment or the other demonstrate unprecedented truancy and ingratitude towards their government employers. The magnitude of dishonesty, embezzlement of public funds, looting government treasuries, diverting public funds and materials to private use, bribery and corruption they practise is inexplicable. Ndukwe (2013) cried out:

Two distinct challenges are insidiously eating away at whatever gains Nigeria has made in the economic arena as well as its socio-cultural stage since pursuing a pro-democratic agenda. What are they? Insecurity and Inconsistent power supply. Lawlessness is a plague that steals the light of a nation. A lawless State is rife with insecurity and its citizens are slaves to such order. Nigeria is witnessing an alarming trend in lawlessness and insecurity. There is hardly any breaking news in the mainstream media without an account of some form of security challenges, acts of violence, ethno-centered strife or religious fuelled clashes. It is either Boko Haram in the Northern corridor or Kidnapping in the South-South and South East geopolitical zone. (The National Question, Monday n20 - 23 May, 2013, p.1).

There is still mutual distrust among the different ethnicities in Nigeria against each other. These and other vices have for decades ravaged our nation due to very poor socialization or complete ignorant of citizenship education. The purpose of education for citizenship is to create sufficient awareness, sensitize both the old and the young to imbibe the spirit of self-reliance, good citizenship, respect for our national emblems and ethics and the desire to build a strong and reliable nation. For our purpose, this paper restricts our discussion to the under-mentioned areas, since they highlight the basic aspects of citizenship education.

i) The concept of citizenship, the state, the Government and the people of Nigeria

ii) The purport of nationality/nationalism 
iii) Acquisition of citizenship, Dual citizenship, deprivation of citizenship

iv) Duties and obligations of citizens to the state

v) Rights and expectation of citizens from the state

vi) National Ethics, Education policy, Economic Policy, National integration, Political socialization, Political Objectives and the need to observe these ideals and aspirations.

Thereafter, recommendations for a functional citizenship education will be put forward.

\subsection{The concept of Citizenship, the State, the Government and the people}

The Concept of Citizenship has been taken care of in the introductory part of this discussion.

\subsubsection{The State}

According to Appadorai(1969), state refers to those social relationships that express themselves through government. The state includes both the Government and the governed. From his point of view, the state is a way of regulating human conduct, it orders us not to murder; it punishes us for a violation of its orders. Ndoh (1997) sees a state as the societal institution which monopolizes the instrument of coercion, the omnipotent institution in a given society. He added that the state exists to facilitate the creative potentials of the individual, and carters for persons in its sphere. Rather than see government as the expression of the state which include both the Government and the governed, but those at the helm of our affairs see government and its business as their individual business, rather than a common wealth and collective responsibility, hence they neglect the governed who have now taken up arms in retaliation. "The pervasive kidnapping of mafia-like phenomenon sweeping across the South-South and South East incenses this pathetic development. Anyone, and particularly those who show signs of wealth are free game for the kidnappers. Foreign nationals are prime victims. There is report that even politicians and feuding leaders employ the services of kidnappers to further their mundane agendas" (Ndukwe 2013).

Different scholars see the state and its purposes in different perspectives. Apart from Karl Marx who saw the state as an instrument for class domination or exploitation, many others saw it as existing for justice and the good life of the citizens. For Thomas Hobbes, the state functions to provide protection for the individual. For Aristotle, the state provides the "Good life". Plato, on his part, says the state promotes justice in the society.

Before the arrival of the colonialists, the different ethnic groups in Nigeria were in existence. The Nigeria state is a child of colonialism. No wonder, Achebe (2012) said: "Great Britain was handed the area of West Africa that would later become Nigeria, like a piece of chocolate cake at a birthday party. Without education for citizenship, Nigerians, particularly, children and youths will not know, let alone appreciate that as a state, Nigeria functions to provide the "Good life" for her citizens, only bad leadership has made her appear an instrument of class domination. "Boko Haram and their unchecked bloody assaults have independently caused a grave loss of revenues to the tune of billions of Naira both for the private and public enterprise. The accompanying human casualties from Boko Haram's onslaught have decimated household's abilities to earn income. The toll on potential foreign investment opportunities is another challenge brought about by insecurity. Foreign multinationals are beginning to dial down on their enthusiasm to venture into our State. This is, despite the known fact that leading evaluators of "developing economics" point to Nigeria as a proven haven for market profitability" (Ndukwe 2013).

\subsection{The Government and People of Nigeria}

Members of every society need to be trained and sensitized towards seeing and appreciating the government as the expression of the state. It is the legislative arm that makes laws for the good governance of the state. The laws need to be executed and interpreted, and these functions the 
Executive and the Judicial arms perform. There is no state without government, else the environment will manifest the anarchy reminiscent of the state of nature. Nigeria runs a federal government with the component states reflecting the diverse ethnicities in the country. The Federal government is the centre of government, and has its seat at Abuja, the component states are responsible to the centre. For the government and people of Nigeria, Chapter II, Section 14(1) of the 1999 Constitution provides among other things: The Federal Republic of Nigeria shall be a State based on the principles of democracy and social justice, and sovereignty belongs to the people of Nigeria from whom government through the Constitution derives all its powers and authority. What lofty ideals for justice and the 'Good life' for us all.

The participation of the people in their government shall be ensured in accordance with the provisions of this Constitution, not with retaliatory followership traits, sadism or devastation of human and material resources. Our lofty ideals and aspirations have been swept under the carpet by the failure of our past regimes to observe the laws. The patience of people are exhausted, hence the followers, particularly the youths, have taken up arms against the government. Ndukwe (2013), quoted Clark Tom, J. as he then was, as saying, in the case of MAPP VS OHIO (1961) 36745, 643: "Our Government is the potent, the omnipresent teacher... for good or for ill, it teaches the whole people by its example. If the government becomes a lawbreaker, it breeds contempt for law; it invites every man to become a law unto himself; it invites anarchy". This is currently the problem with Nigeria - for which insecurity is here.

\subsection{Nationality/Nationalism}

Nationality is synonymous with citizenship. According to Onuoha (1995) nationality refers to a person belonging to a country or nation. There is the need to teach citizens of this great nation that nationalist activities, particularly before independence, need not be neglected, but imitated and continued. Consumed with the spirit of nationalism they, in spite of all odds, formed political parties from which delegations were sent to London to relentlessly press the British government with demands for self-determination for Nigeria. Do we need to define nationalism again, when people like Herbert Macualey, Dr. Nnamdi Azikiwe and Chief Obafemi Awolowo, for example, in demonstration of their strong devotion to Nigeria, struggled through decades for the freedom of Nigeria.

The ways of life that seem to be valued today in our society - armed robbery, swindling, Advanced Freed Fraud, looting of public treasuries, corruption and most recently kidnapping and suicide bombing - are opposed to the spirit of nationalism. Unpatriotic citizens or those ignorance of citizenship education think that the struggle for our independence has ended with the nationalists achieving our freedom from foreign rule. They only achieved weak political independence which has been marred by mismanagement. According to Uzosike (2013), the understanding of citizens that the mismanagement of state resources directly impacts on their individual economy will be the first outcome of their fight which will change the face of governance in the southeast and grow democracy in the right direction. But it is our view that without concrete citizenship education, such understanding will still leave much to be desired, and as such not change the face of governance from and in the right direction.

Political Objectives: The political objectives of Nigeria, among other things, contains the Motto of the Federal Republic of Nigeria, which is unity and Faith, Peace and progress, as enshrined in Section 15 of the 1999 Constitution. Concrete education for citizenship should be drawn up for the youths - to achieve our national integration to prohibit discrimination on the grounds of place of origin, sex, religion, status, ethnic or linguistic association or ties. Only effective citizenship education emphasizing our political objectives and national integration can inculcate a feeling of belonging and of involvement among the various peoples of the Federation, particularly the youths, to the end that loyalty to the nation shall manifestly override sectional loyalties.

National Identity: Identity is something one is known with, something that identifies or marks 
a person out, as a different person, from others. Nigeria takes her pride of place among other nations of the world, as a country unique with symbols that make her enviably different. Our national identities include the Nigeria flag, her national anthem, the pledge, her currency and the plaque. The Nigeria flag is coloured green, white and green. The white colour represents unity and peace, the green symbolizes agriculture.

Education for citizenship is a sine quo non for grooming good citizens - for a strong, selfsustaining and reliable nation. It will instill in the young the love for agriculture which is the major occupation of the people, so much valued by the people that it is embedded on our national flag. Nigeria's national symbol is the Coat of Arm. Citizenship education teaches that the picture and diagrams on the Coat of Arm mean: (i) the black shield signifies the good and fertile land of Nigeria; (ii) the two white horses symbolizes the dignity of Nigeria; (iii) the red Eagle - the strength; (iv) the $Y$ symbol represents the rivers Niger and Benue. Education for citizenship should include sensitizing the masses, especially the youths on our national identity - to infuse in them the patriotic spirit to respect, preserve and guard jealously our symbols and most importantly, be ready and willing at all times to defend our father land.

National Ethics: Majority of people are ignorant of Nigeria's national ethics. No wonder vandalism, violence, social unrests, indolence, religious intolerance, insecurity, have persisted. The 1999 Constitution of the Federal Republic of Nigeria, Section 24 provides that: the national ethics shall be discipline, integrity, dignity of labour, social justice, religious tolerance, self-reliance and patriotism. Without education for citizenship, majority of us will remain ignorant of these and consequently cannot make any meaningful contribution to the society and worst still, constitute nuisance and contravene the laws. These spates of uncanny acts have put the nation in a state of perpetual flight or fright. Law abiding citizens are terrified of moving about as freely as they enjoyed in the past. Business and general commerce are negatively impacted. (Ndukwe 2013). The retaliatory conducts of the led in Nigeria today does not reflect Nigeria's national ethics. Soialization on our national ethics should be spread out across all ages.

Educational Objectives: Education is a Fundamental Objective and Directive Principle of State Policy contained in Chapter II, Section 18 of the Constitution which provides that Government shall direct its policy towards ensuring that there are equal and adequate educational opportunities at all levels. And that Government shall strive to eradicate illiteracy; and to this end Government shall as and when practicable provide - (a) free, compulsory and universal primary education; (b) free university education; and (c) free adult literacy programme. The masses need be socialized on these lofty ideals for all by the government. With the rate of insecurity in the country, and all its attendant loss of human and material resources, government mays not be at liberty to implement these educational objectives.

Economic Objectives: Section 16 of the Constitution provides, among other things that:

The State shall, within the context of the ideals and objectives for which provisions are made in this Constitution harness the resources of the nation and promote national prosperity and an efficient, dynamic and self-reliant economy; control the national economy in such manner as to secure the maximum welfare, freedom and happiness of every citizen on the basis of social justice and equality of status and opportunity. But Uzosike (2013) observed, Fourteen years after the return of civil rule, the southeast zone is still looking impoverished and unattractive to investors. This is after over N9 trillion has been appropriated and greater percentage possibly squandered through fraud, waste and abuse by those we hold as our heroes and great leaders.

\section{Acquisition of Nigerian Citizenship}

Citizenship can be acquired: By birth, By Registration, By Naturalization, by conquest, by Government Concession or Conferment. To acquire Nigerian citizenship, the 1999 Constitution, 
Section 25(1) stipulates: the following persons are citizens of Nigeria, namely;

\subsection{Citizenship by birth}

a. Every person born in Nigeria before the date of independence, either of whose parents or any of whose grandparents belongs or belonged to a community indigenous to Nigeria;

b. Every person born in Nigeria after the date of independence either of whose parents or any of whose grandparents is a citizen of Nigeria is a Nigerian citizen;

c. Every person born outside Nigeria either of whose parents is a citizen of Nigeria is a Nigerian citizen.

\subsection{Citizenship by Naturalization}

In Nigeria, any person who is qualified in accordance with Section 27 of the 1999 Constitution, as amended, may apply to the President for the grant of a certificate of naturalization, and no person shall be qualified to apply for the grant or a certificate of naturalization, unless he satisfies the President that:

i) He is a person of full age, and capacity

ii) Has shown a clear intention of his desire to be domiciled in Nigeria

iii) He is a person of good character

iv) He has been approved by the Governor of the particular state he is or intend to be domiciled, acceptable to the people of that locality he intends to be domiciled, must have been assimilated into the culture or way of life of the locality.

v) He has taken the Oath of allegiance to the Federal Republic of Nigeria

vi) He has made or is capable of making useful contribution to the advancement, progress and well-being of Nigeria.

vii) He has immediately preceding the date of his application, resided in Nigeria continuously for a period of fifteen years.

\subsection{Citizenship by Registration}

In Nigeria, two groups of people can be granted this citizenship. The first is any foreign woman married to a Nigeria indigene, and every person who possesses the requisite age and capacity born outside Nigeria, any of whose grandparents is a Nigerian. Such person may apply for registration as a citizen of Nigeria, if he meets the Presidential requirements.

\subsection{Dual Citizenship in Nigeria/Renunciation of Citizenship/Deprivation of citizenship}

On Dual citizenship, a person shall forfeit his Nigerian citizenship if, not being a citizen of Nigeria by birth, he acquires or retains the citizenship or nationality of a country, other than Nigeria, of which he is not a citizen by birth. A citizen of Nigeria of full age, may renounce his Nigerian citizenship by making a declaration in the prescribed manner for the renunciation, and the President shall cause the declaration to be registered, thereupon the person ceases to be a Nigerian citizen. And the President may deprive a person, other than a person who is a citizen of Nigeria $b$ y birth or by registration, of his citizenship, if he is satisfied that such a person has within a period of seven years after becoming naturalized, been sentenced to imprisonment for a term of not less than three years.

\subsection{Duties and obligations of citizens to the state}

Section 24 of the 1999 Constitution provides that it shall be the duty of every citizen to:- 
a) Abide by this constitution, respect its ideals and its institutions, the National Flag, the National Anthem, the National Pledge, and legitimate authorities;

b) Help to enhance the power, prestige and good name of Nigeria, defend Nigeria and render such national service as may be required;

c) Respect the dignity of other citizens and the rights and legitimate interests of others and live in unity and harmony and in the spirit of common brotherhood;

d) Make positive and useful contribution to the advancement, progress and well-being of the community where he resides;

e) Render assistance to appropriate and lawful agencies in the maintenance of law and order; and

f) Declare his income honestly to appropriate and lawful agencies and pay his tax promptly.

In addition, it is the obligation of all citizens to obey summons to give evidence in Court, if and when called upon to do so, as well as to vote at elections and to be voted for.

\subsection{Rights of citizens from the state}

Chapter IV of the 1999 Constitution of the Federal Republic of Nigeria spells out the Fundamental Rights of the citizens. They are contained in Sections 33 - 43, viz:

1. Right to Life: Every person has a right to life and no one shall be deprived intentionally of his life, save in execution of the sentence of a court in respect of a criminal offence of which he has been found guilty in Nigeria.

2. Right to Dignity of Human Person: Every individual is entitled to respect for the dignity of his person, and accordingly no person, shall be subjected to torture, slavery forced labour or to inhuman or degrading treatment.

3. Right to Personal Liberty: Everyone shall be entitled to his personal liberty and no person shall be deprived of such liberty except in accordance with a procedure permitted by law.

4. Right to Fair Hearing: A person shall be entitled to a fair hearing within a reasonable time by a court or other tribunal established by law and constituted in such manner as to secure its independence and impartiality. Every person who is charged with a criminal offence shall be presumed to be innocent until he is proved guilty.

5. Right to Private and Family Life: The privacy of citizens, their homes, correspondence, telephone conversations and telegraphic communications are guaranteed and protected by the constitution.

6. Right to Freedom of Thought, Conscience and Religion: Every person is entitled to freedom of thought, conscience and religion, including freedom to change his religion or belief and freedom to manifest and propagate his religion or believe in worship, teaching, practice and observance.

7. Right to Freedom of Expression and the Press: Every person is entitled to freedom of expression, including freedom to hold opinion and to receive and impart ideas and information without interference.

8. Right to Peaceful Assembly and Association: Every person is entitled to assemble freely and associate with other persons, and in particular he may form or belong to any political party, trade union or any other association for the protection of his interests.

9. Right to Freedom of Movement: Every citizen of Nigeria is entitled to move freely throughout Nigeria and to reside in any part thereof and no citizen of Nigeria shall be expelled from Nigeria or refused entry thereto or exit therefrom.

10. Right to Freedom from Discrimination: Every citizen of Nigeria of a particular community, ethnic group, place of origin, sex, religion, or political opinion are not made subjects, or accorded any privilege or advantage that is not accorded to citizens of Nigeria of other communities, ethnic groups, places of origin, sex, religions, or political opinions. Consequently, no citizen of Nigeria shall be subjected to any disability or deprivation 
merely by reason of the circumstances of his birth, ethnic group, sex, religion or political opinion.

11. Right to Private Property: Every citizen has the right to own property. No movable property or any interest in any immovable property shall be taken possession of compulsorily and no right over or interest in any such property shall be acquired compulsorily in any part of Nigeria except in the manner and for the purposes prescribed by law.

These rights can be deprived a citizen at any time - in the circumstances prescribed by law.

Political Socialization: According to Ndoh and Ndoh (1997), political socialization is the process of acquiring political beliefs, values, attitudes as well as citizens' political behavior. No other form of instructions and or sensitization can better educate citizens and infuse desirable political behaviours, beliefs, values and attitudes in them other than education for citizenship. No matter how much anybody tries to socialize politically through peer groups, the family, mass media, or political parties, the socialization will still leave much to be desired. Are multitudes of Nigerians not seen, on election days, going about their businesses in utter neglect of their franchise? Some only give it a second thought if they receive some form of gratification. This political apathy is due to lack of citizenship education.

Federal Character: In the days of Constitutional development in Nigeria, there were jeremiad of successive constitutions owing to bitter complaints by Nigerians, either that they were not consulted, that there were no Nigerian members, where they were present, they were very few and only nominated, and were merely unofficial members. As time went on, close to independence, despite claims by the colonial government that some of the later constitutions were designed to promote the unity of Nigeria, there were still bitter complaints that no provision was made to secure greater participation of Nigerians to decide their own affairs.

After independence, the complaints still gathered momentum. This time, the hue and cry were of fears and suspicion that only one or few ethnic groups may hijack the government and the running of the affairs of the whole peoples of Nigeria. The fears were true of the several coup detats witnessed in this country. To alley these fears, unhealthy rivalry and rancour among Nigerians, the Federal Military Government of Nigeria, led by General Murtala Mohammed, in October 1975 introduced the system known as Federal Character into the country. It was embodied in the Constitution. The objective was to promote national unity, foster national loyalty and give every Nigeria citizen a sense of belonging to the nation, irrespective of differences in religion, language, culture and tribe. The spirit and letter of the Federal Character is that, the composition of the government of the federation or any of its agencies and the conduct of their affairs shall be carried out in such a way as to reflect the federal character of Nigeria, by ensuring that there shall be no predominance of persons from a few states or from a few ethnic groups in the government or in any of its agencies.

But there is still clamour of suspicion, antagonism, violence and vandalism due to lack of citizenship education of the citizenry. All our lofty ideals and programmes crumble at implementation due to lack of citizenship education, political apathy and the resultant bad leadership. The patience of the followers appears now to have exhausted, hence insurrections, upheavals, insecurity and all manner of evils persist.

\section{Recommendations}

I have said earlier that education for citizenship is a sine quo none for all citizens, particularly children and the youths who are the leaders of tomorrow. Majority today want to participate in the government of the country, to amass wealth, and nothing more! A citizen who is not trained in citizenship education is deficient in role performance, in fact ignorant of himself, of his immediate environment, the government, the state, and of course, of events beyond his state. It is therefore, hereby suggested that: 
More serious attention be paid to education for citizenship, such that all the levels of education in this country should receive concrete and perfect sensitization on citizenship. The instructors of the course should show examples worthy of emulation. In recommending this, I agree with Osita-Njoku (1997) who opined that children learn most often by imitating their parents and other older siblings they find around them. So, it often does not work when you tell children to do what you say and not what you do. Teaching by good examples is very effective and resultoriented.

Public lectures, in form of cultural heritage programmes should be conducted from time to time for adults, where they should be constantly socialized and sensitized on citizenship education, e.g. on the need for good followership traits, to have faith in the government, contribute their quota to Nigeria's well-being, to shun greed, corruption, dishonesty, political apathy, to respect our symbols, observe the laws, our national ethics and pay their taxes promptly, to respect their fellow citizens rights, to preserve our values, aspirations, behavioural patterns, to promote our lofty ideals and discourage young Nigerians from mass exodus to other countries where their freedom of movement is not guaranteed - they must obtain permits before moving about!

Citizenship Education should be made one of the compulsory corporate social responsibilities of the media, especially for broadcasting houses. They should make songs, jingles and slogans in condemnation of these contemporary social ills - suicide bombing, kidnapping, vandalization, and on the other hand compose same - in praise of our values, aspirations, cultures, beliefs, national symbols and national ethics.

Retaliatory attitudes of followers, especially the youth, are the contemporary social problems plaguing Nigeria. Prolonged bad leadership by those at the helm of affairs has degenerated into insecurity in the country. The patience of the led appear to have vanished, hence the youths cash on the slightest opportunity to steal, to kill, kidnap, bomb, stir up violence, and rob - just to retaliate the wrongs of the leaders. The belligerents, in the form of militants, boko haram or the like, appear to have been provoked to actions and the feeling that it is now their turn to turn the country upside down. Only concrete and effective citizenship education can purge our nation of these social vices.

The family, the first agent of socialization of a child, gulped in the quest for wealth, the result has been multi-dimensional - juvenile delinquency, truancy, cultism, dishonesty, sharp practices, kidnapping, examination mal-practice, armed robbery hold the nation hostage. It is recommended here that the perpetrators of these evils should be apprehended along with their parents, their names, and home addresses published in newspapers, and announced over the television and radio for consecutively six months preceding the offence. Parents should partake in the punishment arising from their children or wards' prohibited acts. It will make parents leave up to their responsibilities.

The rule of law should be observed religiously. The observation by the masses that government actions are guided by law and that there is a reasonable balance between state powers and individual freedom will quell belligerency in Nigeria.

Granted but not conceding that Citizenship education has been made a General course in our tertiary institutions, that is only a step towards realizing the objectives. There is the dire need to teach, sensitize, socialize, and to continue teaching, sensitizing and socializing the learners and adults as well till we achieve the objectives. This paper emphatically recommends that the instructions already contained in the Course, and a lot more discussed herein be spread out to reach all ages of the Nigerian citizenry, especially to all levels in school, according to their relevance.

The youths should lay down arms and insists on citizenship education, allow no one to influence or deceive them to take to thuggry or vandalization of any sort, or bombardment and killing fellow innocent citizens. The youth should shun the popular evil slogan: "If you can't beat them join them"! No two wrongs ever made a right! Let us sow good seeds today that our harvest may be plenty tomorrow. 


\section{Conclusion}

One may wonder or question why the writer chose to dwell on this common topic, and still laying emphasis on socializing, training and sensitizing citizens, particularly the young on concrete and effective citizenship education, while Citizenship Education has been made a General Course of study in our higher institutions for over a decade. The answer is that the aims and objectives of introducing the Course in the schools have not been achieved. There is still, on the increase, persistent mutual distrust among the heterogeneous tribes of Nigeria against each other. The monster of official corruption is also waxing stronger daily, irrespective of the presence of EFCC, ICPC, SERVICOM, etc. Some persons at the helm of affairs of these Commissions and others like them are too corrupt to occupy the posts. While the notoriety of our youths rises daily internally and internationally, indolence, cultism, armed robbery, bribery, embezzlement of public funds, dishonesty and sharp practices are still staring us on the face. Prolonged bad leadership has provoked and sparked the led into action and paved ways for new strange crimes - kidnapping, suicide bombing, ritual killing and violence everywhere.

The entire citizenry need to conduct themselves properly first, with effective citizenship education, we will soon realize the noble ideals enshrined in our Constitution for our good. I pinch my tent with Azikiwe (1997) who said: "My view is that whilst we must admit that Nigeria is multilingual with variegated cultures, there are some unifying elements in its conflicting ideologies which could be harmonized by adaptation to modern criteria and practices. If progenitors could create a social atmosphere which was stable and it enabled them to survive the struggle for existence, it is logical to conclude that their ideology worked. The practicability of their ideology is sufficient justification for us, their successors, to build on such a foundation, especially in view of our higher intellectual attainments in a civilization that is more sophisticated than what our precursors were accustomed to". With rich mineral and human resources in Nigeria, the sky is our limit, what lacks is effective and proper sensitization and socialization orientation which citizenship education for all, especially the youths, offers.

\section{References}

Achebe, C. (2012). There was a Country: A personal History of Biafra. U.S. Penguin Press.

Appadorai, A. (1969). The Substance of Politics. Madrid. Oxford University Press.

Azikiwe, N. (1980). Ideology for Nigeria: Capitalism, Socialism or Welfarism? Lagos. Macmillan Nigeria Publishers Ltd.

Ndoh C. A. (1997). Meaning and Purpose of Citizenship. In: Citizenship Education for Nigerian Universities. Owerri. Achugo Publications.

Ndoh C. A. and Ndoh, Priscilla (1997). Political Socialization Process. In: Citizenship Education for Nigerian Universities, Owerri. Achugo Publication.

Ndukwe, E. (2013). "Insecurity and Inconsistent Power Supply: The Two distinct challenges draining the gains of our economy". In: National Question, Monday 20 - 23 May, 2013.

Nkang, I. E. (2007). The 6-3-3-4 Educational Reforms and the Quality of Secondary School Administration in Akwa Ibom State. In: Empirical Journal of Quality Education (EJOQUE), Vol. 2. A publication of the Association for Promoting Quality Education in Nigeria. (APQEN).

Onuoha, J. E. (1995). Citizenship Education in Nigeria. Owerri. Vivian \& Vivians Publishers Ltd.

Osita Njoku, A. (1997). Socialization Processes (A Sociological Perspective). In: Citizenship Education for Nigerian Universities. Owerri. Achugo Publications.

Uzosike, C. (2013) "Grapevile: As Civil Cociety Organisations call for budget access and participation in South East to fight corruption". In: National Question, Monday 20 - 23 May, 2013.

The 1999 Constitution of the Federal Republic of Nigeria (as Amended), 2011.

Mapp Vs. Ohio (1961) 367 U.S., 643.

Olmstead Vs. U.S. (1928) 277 U.S., 438. 